\section{New Cinemas}

Journal of Contemporary Film

\section{Volume 13 Number 1}

Special Issue: (In)visible cinemas: Reusing archival footage in Latin American cinema

Introduction

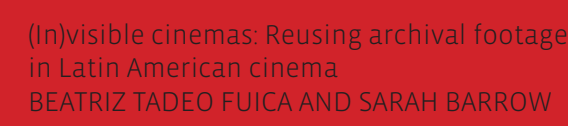

Articles

\section{Reviews}

\section{New Cinemas}

Journal of Contemporary Film

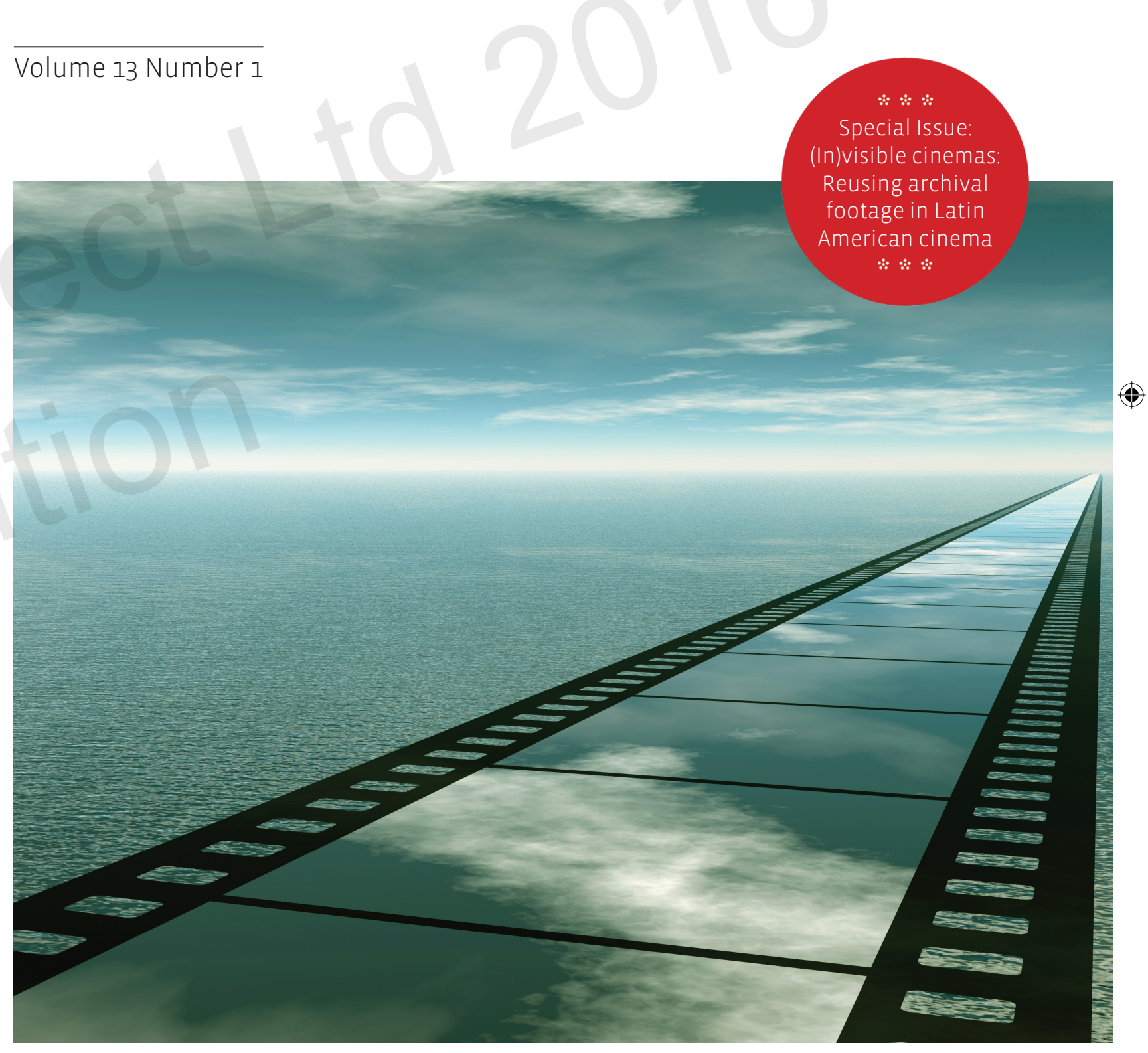

i intellect Journals

ISSN 1474-2756 